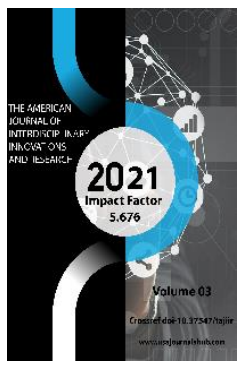

Copyright: Original content from this work may be used under the terms of the creative commons attributes 4.0 licence.

\section{The Plan Of Internal Control Of The Educational Institution And Its Implementation}

\author{
Yusup Ganievich Makhmudov \\ Doctor Of Pedagogical Sciences, Professor Of The Department Of "General Physics" Of \\ Termez State University, Uzbekistan \\ Zulfikor Juraevich Kholmirzaev \\ Director Of The Academic Lyceum At The Toshkent Chemical And Technological Institute, \\ Uzbekistan
}

\begin{abstract}
In this article it has been described the plan of the internal Control of educational establishments and its fulfilment.
\end{abstract}

\title{
KEYWORDS
}

System, activity, control, work, state, documents, cooperation, form, method, methodic, efficiency, qualification.

\section{INTRODUCTION}

In management activities, the role of a certain system is very important. This activity should not consist of random and unrelated activities. It should be developed taking into account the conditions, circumstances and features of the tasks assigned to the entire society and its individual links. It consists of a series of deeply 
and carefully considered, closely interrelated and strictly systematized planned activities.

The plan of an educational institution for internal control can be drawn up for one quarter, for six months, and for the entire academic year. However, it is advisable to make a plan for one academic year.

The internal control plan developed by the head of the educational institution may include the following issues::

1. Implementation of the national economy plan for all indicators of the educational institution.

2. The state of educational and educational work.

3. Educational work carried out outside the classroom and outside the educational institution.

4. Works carried out by the public of the educational institution together with the patronage organizations and basic enterprises.

5. Work with the teaching staff of the educational institution (improving the political, scientific, methodological and pedagogical level of teachers).

6. The state of documentation management in the educational institution.

7. Work of the youth organizations of the educational institution.

8. Financial and economic activities of the educational institution.

9. Cooperation of the educational institution with families and the public.

10. The work of class teachers and other issues.
It should be noted that the forms and methods of internal control of an educational institution are different. The question arises as to how and to what extent to exercise control. All this depends on the political, scientific, methodological and pedagogical level of the head of the educational institution, as well as on how hard he will treat this issue.

The internal control of an educational institution can be divided into two groups, depending on the issue under consideration: a) thematic control of the activities of an educational institution; b) comprehensive frontal control of an educational institution.

The thematic control may include the following questions:

1. The state of implementation of the state curriculum in the humanities of an educational institution.

2. Increase the ability of logical thinking of students in the process of learning the basics of subjects.

3. Experience of the relationship between education and upbringing in physics lessons in an educational institution.

4. Improving the speech culture of students when teaching their native language and literature.

5. The state of practical work in the lessons of history and geography.

6. Formation of the scientific worldview of students in teaching chemistry, biology, physics.

In addition, the object of thematic control can be the study of the best practices of 2-3 teachers of various specialties, the work of class teachers, the activities of methodological 
associations of teachers of history and geography, native language and literature.

Comprehensive control of the activities of an educational institution sets a goal: to comprehensively study the issues of multidimensional pedagogical activity, covering the educational and educational and economic spheres. For example:

1. The state of teaching exact disciplines in an educational institution and measures to improve them.

2. The state of implementation of extracurricular activities and works outside the educational institution and the state of their improvement.

3. The state and effectiveness of professional development and retraining of teachers of an educational institution.

4. The state of provision of students with educational literature and textbooks and measures to improve this issue.

5. The state of the issue on the use of folk pedagogy in the educational system of an educational institution and ways to improve it.

6. The state of teaching social and humanitarian disciplines in an educational institution and the level of knowledge of students.

7. The state of implementation of the tasks of education in an educational institution in accordance with the modern requirements of secondary and secondary vocational education. It is advisable to discuss the results of the inspections of these issues at the pedagogical councils of the educational institution.
If the internal control of an educational institution is conducted in a variety of forms and methods, then it is possible to solve its main tasks, that is, to determine the quality of the curriculum and program, the ideological and political level of training, the relationship of education with education in the learning process, comprehensive high-quality scientific, methodological and general pedagogical training of teachers for lessons, their use of effective teaching methods, the level of knowledge of students.

In the internal control system, the examination period is a responsible period in the life of an educational institution and can serve as a general assessment of the knowledge, skills and abilities of students. When analyzing the oral and written answers of students in the exams, the main attention should be paid to how they have mastered the most important parts of each subject, the mastery of the theoretical course, the skills of commenting on the phenomena of society and nature based on theoretical knowledge, the skills of independent thinking, the skills of performing practical tasks and laboratory work.

One of the reliable methods and optimal means of obtaining reliable information about the internal control of an educational institution is the method of statistical analysis. In the activities of an educational institution, there is a lot of statistical information, on the basis of which the following types of work can be carried out:

- Studying the progress of students of any classes in subjects and the dynamics of the movement of their contingent in an educational institution; 
- The results of the written control of the same level of complexity, conducted in parallel classes at the same time, the shortcomings in the knowledge of students, their mistakes, a comparative analysis of written works for several years, to analyze all the works and make an appropriate conclusion;

- Familiarization with the monitoring of the use of educational literature by students in their free time in the information and resource center of the educational institution;

- Accounting for the employment of graduates of an educational institution or their further place of study, their sociopolitical and labor activities, and others. In this case, the task of the head of an educational institution is: to master the method of statistical calculation well, to skillfully apply this method in the analysis and description of all events from the life of an educational institution.

Taking into account the specifics of the teaching methodology of each subject in the analysis of the state of learning occupies a special place in the internal control system.

It should be noted that there are not so many heads of educational institutions in our Republic, but unfortunately there are such heads and their deputies who superficially look at the issue of managing an educational institution, in particular, the implementation of internal control.

The following shortcomings are observed in the implementation of internal control of educational institutions:
1. In some educational institutions, internal control is not carried out in full compliance with all the management regulations and not in accordance with the plan drawn up on a scientific basis.

2. In some educational institutions, the implementation of internal control does not always meet the requirements for the distribution of work at the beginning of the school year for cooperation between the heads of educational institutions and public organizations, as a result of which there are repeated shortcomings in the implementation of internal control in educational institutions. Internal control, carried out in this way, does not give the desired effect.

3. In the system of internal control of some educational institutions, state and government resolutions on public education do not find their implementation. As a result, the management principle is violated.

4. Another important issue of the system of internal control of educational institutions is the issue of mutual attendance of teachers ' lessons and members of method associations in subjects. This important issue in some educational institutions of our republic does not meet the requirements. For example, in some educational institutions where we monitored, the total number of hours of mutual attendance of teachers during the year does not coincide with the planned amount of teaching load. Teachers must attend at least 2 hours of class each day.

5. In some educational institutions where we got acquainted with educational activities, the following important issues remained outside the field of internal control: 
a. The state and effectiveness of extracurricular educational work and work of extracurricular institutions;

b. The state of operation of the information and resource center of the educational institution;

c. The state and effectiveness of work to improve the skills of teachers from the political, scientific, methodological and pedagogical points of view;

d. The state of financial and economic work of educational institutions (report of the deputy heads of educational institutions on economic affairs on this issue);

e. The results of work on the cooperation of subject teachers, class teachers and parents in improving the quality and efficiency of the educational process of students;

f. The state of provision of students with hot food;

g. Pedagogical agitation and propaganda activities, as well as the state of documentation management in the educational institution and other issues remain outside the scope of internal control. The attitude of the heads of some educational institutions to the issue of managing the activities of educational institutions, in particular, to the organization of internal control, has a negative impact on the improvement of educational and educational work.

\section{REFERENCES}

1. Akhmidinov R. Sh. The management system of a general education institution. Tashkent: "Ukituvchi", 2002.
2. Mirkasymov M. A. Work on improving the professional skills and retraining of teachers. - Tashkent: "Uzbekistan", 1992.

3. Boymirov Sherzod., Ashirov Shamshiddin., Elmurotov Rustam., Davlatov Utkir., Mamatov Abduraim., Urozbokov Alijon. Principles of Selecting Materials For Problem Based Training In The Section Electrodynamics Physics // Solid State Technology. ISSN 0038-11IX Volume: 63 Issue: 4, 2020.

4. Ashirov Shamshiddin, Mamatov Abdurayim, Boymirov Sherzod, Sattarkulov Komil \& Daminov Rahim. Development of problem technology of teaching in physics // European Journal of Research and Reflection in Educational Sciences. ISSN 2056-5852 Vol.7No. 12, 2019.

5. Yusuf Makhmudov., Sherzod Boymirov. Educational and creative activity of the student and technology of its management in problem teaching of physics // European Journal of Research and Reflection in Educational Sciences. ISSN 2056-5852. Vol.8 No. 2, 2020. 